\title{
Pseudomyogenic Hemangioendothelioma
}

National Cancer Institute

\section{Source}

National Cancer Institute. Pseudomyogenic Hemangioendothelioma. NCI Thesaurus.

Code C121668.

An intermediate, rarely metastasizing blood vessel neoplasm that more frequently

affects young adult males and usually arises in the lower limbs. In approximately half of the affected patients the tumor is painful and in two-thirds of the patients the tumor is multifocal. Morphologically it is characterized by the presence of sheets and fascicles of spindle cells with abundant eosinophilic cytoplasm and vesicular nuclei. Cytologic atypia is usually mild. Approximately $60 \%$ of the patients develop local recurrences or additional tumors in the same anatomic region. 